\title{
Britain's libel fighter
}

Published at www.cmaj.ca on Oct. 4

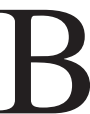
ritish science writer Simon Singh wrote two sentences in 2008 that ended up costing him $£ 200$ 000. Singh doesn't regret writing them, however, because those 51 words may also end up helping to change Britain's draconian libel laws, which are infamous for stifling public debate on important topics in medicine and science.

Singh, who has a $\mathrm{PhD}$ in particle physics, is the author of several bestselling books, including Fermat's Last Theorem and Big Bang. He also produces documentaries and has received several awards for making complex topics in mathematics and science accessible to the public. In 2008, Singh and Dr. Edzard Ernst, a professor of complementary medicine, published a book called Trick or Treatment?, which evaluates the scientific evidence supporting alternative medical treatments, including acupuncture, chiropractic, homeopathy and herbal medicine.

"We are not anti-alternative medicine," says Singh. "We are pro-evidence."

To promote the book, Singh gave lectures and wrote articles on the topics it covered. One of those articles, a commentary published in The Guardian newspaper during Chiropractic Awareness Week, challenged claims made by the British Chiropractic Association that spinal manipulation could treat many childhood health problems (www .guardian.co.uk/commentisfree/2008 /apr/19/controversiesinscience-health).

"The British Chiropractic Association claims that their members can help treat children with colic, sleeping and feeding problems, frequent ear infections, asthma and prolonged crying, even though there is not a jot of evidence," wrote Singh. "This organisation is the respectable face of the chiropractic profession and yet it happily promotes bogus treatments."

These two sentences did not sit well with the British Chiropractic Associa-

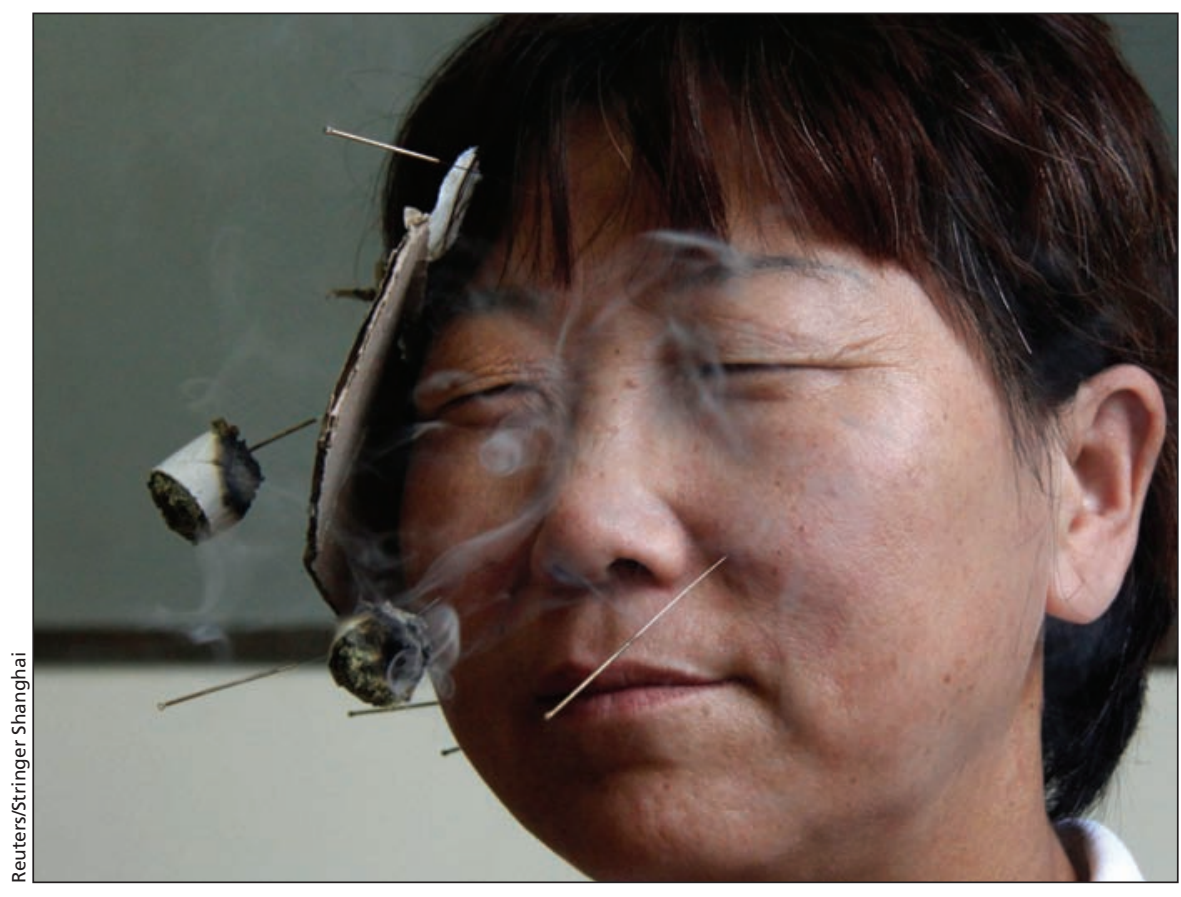

A patient receives a traditional Chinese medical treatment with needles and ignited dry moxa leaves to cure facial paralysis.

tion. The Guardian offered the association an opportunity to reply to Singh's commentary, but it refused. Instead, it asked for a personal apology from Singh — an apology it would not receive.

"I was not prepared to apologize for saying things that are true," says Singh.

The association then decided to sue Singh for libel. A preliminary hearing was held at the Royal Courts of Justice on May 7, 2009, during which the judge ruled that Singh had stated - as a matter of fact, rather than opinion that the British Chiropractic Association was being consciously dishonest by promoting treatments it knew didn't work. This was not a fair interpretation, says Singh, who insisted he had merely offered his opinion on the scientific merit of the treatments, not on the honesty of the association, which would be impossible to prove or disprove.

"The trouble with libel in Britain is that it is so stacked against the writer," says Singh. "Any journalist, from day one, has to fight an uphill battle."
Britain's libel laws are notorious the world over for stifling free speech. The laws favour the complainant so much, in fact, that the United Kingdom is known as the "libel capital of the world" and has become a popular destination for "libel tourism." An investment bank in Iceland once sued a Danish newspaper for libel in England. A rich Russian businessman once took New York-based Forbes Magazine to a British court for libel. As long as a company has business dealings in Britain and the offending media article or book can be read by potential customers (even on the Internet), it can sue a journalist anywhere in the world for libel in the United Kingdom.

"Britain is crushing free speech in the rest of the world," says Singh. "People who have genuine concerns about drugs won't put those concerns into print because of the threat of libel."

Supporters of free speech in scientific debate quickly rallied around Singh. To draw attention to the case, 
the charity Sense About Science launched its "Keep Libel Laws out of Science" campaign (www.senseabout science.org.uk/index.php/site/project 1341/). Dr. Ben Goldacre, author of the popular "Bad Science" column in The Guardian, wrote that the public is put at great risk when debate is discouraged in the field of medicine (www.guardian .co.uk/commentisfree/2010/apr/15/simon -singh-libel-medical-review).

"But most damnable is that this case has taken place in the arena of medicine, where reasonable criticism of each others' practises should never be stifled, for one simple reason: it's possible, in medicine, to do enormous harm, even when you set out with the best of intentions," wrote Goldacre.

Singh appealed the judge's decision and, on April 1, 2010, the Court of Appeal ruled that Singh's criticisms of the British Chiropractic Association were "fair comment." Two weeks later, the association dropped its charges of libel against Singh. Though the case cost him $£ 200000$ in legal fees, and two years' worth of work, Singh believes it may serve as a turning point in the battle to reform Britain's libel laws.

The case bolstered support for the Libel Reform Campaign, a cause organized by several free speech advocacy groups (www.libelreform.org). The government has also taken notice. All three political parties have promised to reassess Britain's libel laws. High-profile libel cases such as Singh's may also have been a factor in the passing of a new US law, signed by President Barack Obama in August, to protect US writers from being sued for libel in other countries. The law is based on New York's Libel Terrorism Protec- tion Act, passed in 2008 after a Saudi Arabian businessman sued a US academic for libel in a British court.

Singh would like to see Britain adopt a law permitting a defence of public interest in cases of libel. This would permit writers more freedom to discuss medical and scientific topics of importance to society without fear of being sued. He also wants the government to reduce the costs of defending against charges of libel, which are so high that many people can't afford to even try. Overall, however, the future is looking brighter for science and medical writers in Britain, says Singh. "I genuinely believe that the libel laws will change in England, which will have global significance." - Roger Collier, $C M A J$

DOI:10.1503/cmaj.109-3673 